\title{
Physical characteristics of reticular content in the bovine and consequences on reticular outflow
}

\author{
C Dardillat, R Baumont
}

\author{
INRA, Station de Recherches sur la Nutrition des Herbivores, \\ Centre de Recherches de Clermont-Ferrand/Theix, 63122 St-Genès-Champanelle, France
}

(Received 23 April 1991; accepted 22 October 1991)

\begin{abstract}
Summary - Reticular content was sampled in cows before and 2 and 5 hours after they were fed various forages. Dry matter, particle size distribution, $\mathrm{pH}$, osmotic pressure and viscosity of the liquid phase were measured. Consistency was also evaluated using purpose-built apparatus. The contents were fractionated by vertical distribution under gravity and by intermittent flow through an orifice into fractions containing different particle concentrations, to model reticular retention of large particles in rumen outflow. Retention occurs as a result of a combination of flotation carrying large particles back into the rumen, and filtration which prevents them leaving it. These processes are particularly effective after feeding, and with poor hay, and so help prolong fermentation time. The consistency of reticular content is relatively stable; it may be autoregulated by adjustment of feeding parameters in response to sensory receptor signals.
\end{abstract}

reticulo-rumen / digestive content / particle sorting / outflow / bovine

Résumé - Caractéristiques physiques des contenus réticulaires chez le bovin et conséquences sur le flux à la sortie du réseau. Le contenu réticulaire de vache a été prélevé avant, 2 ou 5 heures après la distribution de divers fourrages pour mesurer la matière sèche, la taille des particules, le $\mathrm{pH}$, la pression osmotique, la viscosité de la phase liquide, et, par des méthodes spécifiquement mises au point, la consistance du contenu, ainsi que sa séparation, par gravité ou par écoulement discontinu, en fractions plus ou moins riches en particules. Ces séparations qui ont pour but de modéliser la rétention réticulaire des grandes particules dans la vidange ruminale montre que cette rétention procède de la conjonction d'un phénomène de flottation qui permet le retour des grandes particules vers le rumen et d'une filtration qui s'oppose à leur sortie. Ces phénomènes sont particulièrement efficaces après le repas et pour les foins pauvres, ce qui contribue à assurer un temps de fermentation prolongé. La consistance du contenu réticulaire, relativement stable, pourrait être régulée par l'ajustement du comportement alimentaire.

réticulo-rumen / contenu digestif / tri des particules / transit / bovin 


\section{INTRODUCTION}

In ruminants, the reticulum is the site of various types of ororuminal and intergastric circulation that have been described by radioscopy in the sheep (Wyburn, 1980); comparable results have been found in bovines (Kennedy, 1985).

The ingested bolus passes rapidly at the top of the reticulum, from the cardia to the dorsal sac; the rumen gases vent in the opposite direction during the secondary contractions of the rumen (Wyburn, 1980). The liquid ingesta (drink, saliva, juice expelled during rumination) access directly to the reticulum and even to the abomasum during closure of the oesophagal groove which can occur at certain not well-defined occasions in the adult (Mackintosh, 1984). During rumination, the contents situated in the top part of the reticulum are regurgitated with return of the fluid part into the reticulum and of the ruminated bolus towards the dorsal sac (Ehrlein, 1980). A rapid exchange of contents between the reticulum, atrium and reticulum occurs at each reticular contraction, resulting in drainage towards the reticulum of the fluid content from the ventral sac (Waghorn and Reid, 1977). Emptying of the reticulum towards the omasum occurs in a pulse at the end of the second reticular contraction followed by reflux (McBride, 1984; Deswysen, 1985; Dardillat, 1987).

The reticular content is therefore composed of ruminal effluent, ie the "digested" part of the rumen contents ready for further processing in the omasum and abomasum, and material in transit that has just been ingested or is ready for rumination. Sorting mechanisms come into play that result in fine particles being let into the omasum while large particles are retained in the reticulo-rumen. Various explanations have been proposed for this selective retention: Weich and Smith (1978) suggest that fine particles pass through an entanglement of large particles, while King and Moore (1957), like numerous other authors cited by Sutherland (1988), suggest that the high density of the fine particles causes them to settle out and accumulate in the ventral part of the reticulum where they are most likely to be evacuated through the reticulo-omasal orifice (ROO). Reid (1984) suggests that the contents may be canalized towards the ROO in the channels formed by the reticular honeycomb during contraction of the reticulum. In the reticular content of the cow, floating of the large particles and filtering of the contents at the $\mathrm{ROO}$ as sorting mechanisms may vary in effectiveness according to diet and stage of digestion (Dardillat and Baumont, 1988). Finally, omaso-reticular reflux of large particles retained in the omasal canal may be involved (Ehrlein, 1980; McBride, 1984; Dardillat and Baumont, 1992).

The rate of emptying of the rumen and the retention of feed in the forestomachs and subsequent filling of the rumen may thus be closely linked to physical characteristics of the reticular content such as particle size distribution (Poppi et al, 1980), dry matter (DM) content, viscosity and propensity to separate out by flotation or filtering. The aim of this work was first to develop methods to study the consistency of the reticular content and the dynamics of the particles inside the reticulum as well as during the outflow through the reticuloomasal orifice. These methods were then used to investigate these phenomena during feeding of different diets.

\section{MATERIALS AND METHODS}

\section{Animal preparation}

Two Jersey cows weighing $300 \mathrm{~kg}$ were fitted under halothane anaesthesia with a flexible ru- 
minal cannula $115 \mathrm{~mm}$ in diameter. This cannula was designed for easy introduction of the arm and various pieces of apparatus into the rumen and for tight fit regardless of the fistula diameter. It consisted of a section of lorry tyre inner tube riveted onto a flexible PVC flat ring moulded and oven-polymerized. Its other end was crenellated and perforated. For fitting, the rubber was stretched over a second flat PVC ring identical to the first (fig 1), and held to it with bolts. A third flat PVC ring was then clamped onto the second ring using these bolts, thereby holding the rubber firmly in place. The third stiff ring had a threaded inner edge into which a hatch of the same material could be screwed. The hatch had a rentral bung hole. This cannula affords a perfect fit whatever the morphology of the fistula, either tight or loose to avoid necrosis. It can easily be replaced without any prior dilation of the fistula.

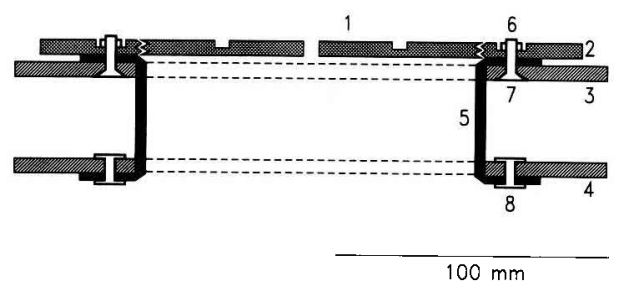

Fig 1. Saggital cross section of ruminal cannula. 1), Screw-in stiff PVC hatch with central orifice closed with rubber bung; 2 ), threaded stiff PVC ring; 3 and 4), flexible PVC rings; 5), cylindrical rubber cannula; 6 and 7 ), nut and bolt; 8 ), rivet. The length of the cannula is adjusted for the required fit by pulling it over the bolts, piercing the rubber at the appropriate places and clamping.

\section{Feeding}

Forage was distributed once daily at 8:30 am ad libitum ( $10 \%$ refusal). Four diets were offered for 2 months: early cocksfoot hay, lucerne hay, late mixed meadow grass hay and the same after $2.5 \mathrm{~kg}$ of milled barley, which the cows ate in a few minutes. The feed composition is set out in table I. Water distribution was discontinued half an hour before each sampling time to avoid dilution of the reticular content.

\section{Sampling}

Three to 5 I of reticular content was sampled in a single take either before the morning distribution or 2 or 5 hours thereafter. One sample was taken per cow per day. For each diet, 4 samples were taken per cow at each time. Sampling was performed using a vacuum cleaner hose $38 \mathrm{~mm}$ in inside diameter connected via a tap to a vacuum pump to reduce the pressure just sufficiently to afford mild suction. The free end of the hose was led manually through the contents of the rumen to the reticulum and held at finger's length from its end. Under these conditions, 3-5 I of reticular content was sucked up in 2-5 s.

Measurements of vertical particle distribution and consistency were made immediately after sampling.

$\mathrm{pH}, \mathrm{DM}$, particle size distribution and flow through an orifice were measured shortly afterwards. Viscosity of the liquid phase and osmotic pressure were measured on frozen spun supernatants. Trials had shown that such storage did not affect the values of these parameters.

Table I. Chemical composition ( $\mathrm{g} / \mathrm{kg}$ dry matter (DM) and digestibility of the 3 hays used.

Lucerne Cocksfoot Mixed grass

$\begin{array}{llll}\text { Organic matter (OM) } & 878 & 896 & 918 \\ \text { Nitrogen } & 31.7 & 31.4 & 13.6 \\ \text { Neutral detergent fibre } & 447 & 637 & 684 \\ \text { Acid detergent fibre } & 312 & 298 & 396 \\ \text { Acid detergent lignin } & 72 & 33 & 57 \\ \text { DM (g/kg fresh weight) } & 855 & 878 & 884 \\ \text { In vitro OM digestibility }(\mathrm{g} / \mathrm{g}) & 0.638 & 0.658 & 0.541\end{array}$


To include 3 other diets, previously obtained results were used with one of these cows. The feed was crushed and pelleted lucerne and 2 fresh forages cut daily, meadow grass and lucerne, and offered once a day ad libitum. For each of these diets, 8 samples were taken before and $\mathbf{5}$ hours after feed distribution and the total DM, particle size distribution, vertical distribution pattern under gravity, filtration through an orifice and consistency were all measured.

\section{Physical measurements}

\section{Vertical distribution of particles under gravity}

To study this, a purpose-built cylindrical vessel was used (fig 2) made up of 3 flanged compart-
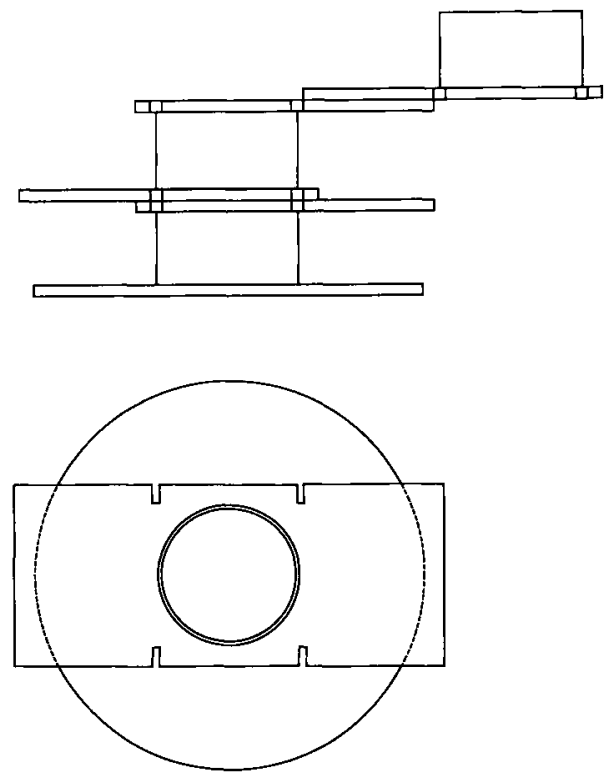

$100 \mathrm{~mm}$

Fig 2. Side and top views of apparatus used to measure vertical displacement of particles under gravity. Before filling, the 3 compartments are placed on top of each other to form a single cylinder (top view); the side view shows the top compartment slid to one side to collect the top fraction; the middle fraction is collected likewise. ments that slid apart in such a way that the top, middle and bottom thirds of the contents of the whole cylinder could be separated at any time. Immediately after sampling, $1 \mathrm{I}$ of reticular content was poured without stirring into the vessel which was then left on a water bath at $39^{\circ} \mathrm{C}$ for $10 \mathrm{~min}$. The 3 fractions were then separated and DM and particle size distribution determined in each.

\section{Flow through an orifice}

Flow of reticular content through an orifice the size of the ROO is rapidly arrested by the formation of a plug of particulate matter. The small volume that does pass through is thus partly filtered (Dardillat, 1990). To study this we used a basin with a stoppable hole $18 \mathrm{~mm}$ in diameter cut out in the angle between the bottom and the side, and a stirrer fitted with blades spanning the diameter of the basin, turning $2 \mathrm{~cm}$ above its bottom at one revolution per $s$. Two I of reticular content was stirred in this way to model the rapid tangential movement of the reticular content past the open ROO. The orifice was then unstopped and fluid allowed to run out until flow became naturally obstructed by formation of a plug. This took several s.

The outflow from 10 successive tappings was collected for determination of DM and particle size distribution.

\section{Consistency}

Consistency is a difficult parameter to define for a such a highly heterogeneous material as gastric content (Dardillat, 1990). The volume collected from the apparatus described above is one measure of consistency; this will be called consistency "volume" to differentiate it from a second, simpler measure which we call the consistency "diameter". This is the diameter of the narrowest orifice through which the reticular content will flow under gravity in its entirety. To measure this, we used a $1-1$ cubic box and a set of lids with 2 holes cut at opposite corners ranging in diameter from $20-40 \mathrm{~mm}$ in 2-mm steps. The box was filled with reticular content and a lid put on it. The box was then tipped over. The minimum lid hole diameter through which the box could be completely emptied was then taken as the consistency "diameter". 


\section{Particle size distribution}

Particle size distribution of total contents, the 3 fractions obtained by vertical distribution under gravity and that obtained by flow through an orifice were determined by wet sieving (Grenet, 1970). Six square mesh sieves $(8,4,2,1,0.4$ and $0.05 \mathrm{~mm}$ ) were used. After oven-drying at $95^{\circ} \mathrm{C}$ for $24 \mathrm{~h}$, the quantity of particles retained on each sieve was weighed. The results are expressed in $\mathrm{g}$ DM per $\mathrm{kg}$ of fresh reticular matter. The size of the particles are expressed as the mesh size of the retaining sieve, although the actual length of the particles is about $2 \sqrt{2}$ times greater than this quantity (Vaage et al, 1984). To simplify the analysis of the result, 3 classes of particles were distinguished: "large" particles (mesh 8 and $4 \mathrm{~mm}$ ), "medium" particies (mesh 2 and $1 \mathrm{~mm}$ ) and "small" particles (mesh 0.4 and $0.05 \mathrm{~mm}$ ). In the cow, the large particles so defined cannot leave the forestomachs (Dardillat and Baumont, 1992). The DM in the final sieve effluent contained soluble matter, microorganisms and very fine food particles.

\section{Osmotic pressure and viscosity of the liquid phase}

For each sample, a supernatant was obtained by spinning at $15000 \mathrm{~g}$ for $10 \mathrm{~min}$. The osmotic pressure of these supernatants was measured by cryometry and their viscosity was determined using a capillary viscometer of internal diameter $0.8 \mathrm{~mm}$.

\section{Statistical analysis}

An analysis of variance was performed on the results of the main study (4 diets, 3 times and 2 cows, ie 24 observations for each parameter studied). The model used contained the effects of diet (3 DF), sampling time (2DF), cow (1 DF) and of the interaction between diet and sampling time (6 DF), ie $11 \mathrm{DF}$ in the error term. The calculations were performed using the general linear model procedure of the Statistical Analysis System Institute (1985).

The results obtained for the 3 additional diets are presented as means $\pm S D$.

\section{RESULTS}

\section{Feed value of hay and intake}

Cocksfoot and lucerne hays were more digestible than mixed grass hay: both had a higher nitrogen content, and lucerne hay had a lower NDF content (table 1). Accordingly, cocksfoot and lucerne hays were ingested in significantly greater amounts than mixed grass hay (table II). The amount of mixed grass hay fell slightly after $2.5 \mathrm{~kg}$ of barley, but the total DM intake was then markedly higher.

Analysis of variance carried out on the results of the main study failed to reveal any significant interaction between the effect of the nature of the diet and the time after feeding on any of the parameters tested (ie intake, dry matter and particle size distribution of total contents, of vertical distribution fractions and of filtered fractions) other than $\mathrm{pH}$ and osmotic pressure.

\section{Dry matter content and particle size distribution}

Representative sampling of reticular content is difficult: manual scooping of content can result in loss of liquid phase, while suction up through a tube tends to undersample the solid matter. For the rumen, only complete emptying affords satisfactory samples. For the reticulum, sucking up the contents through a $38-\mathrm{mm}$ hose gave satisfactory results; draining effects were avoided since it took only 1 or $2 \mathrm{~s}$ to remove most of the contents. Also, any occlusion of the free end of the hose by the reticular wall that might have filtered the sample was easily detected by palpation. In such cases a new sample was taken. 


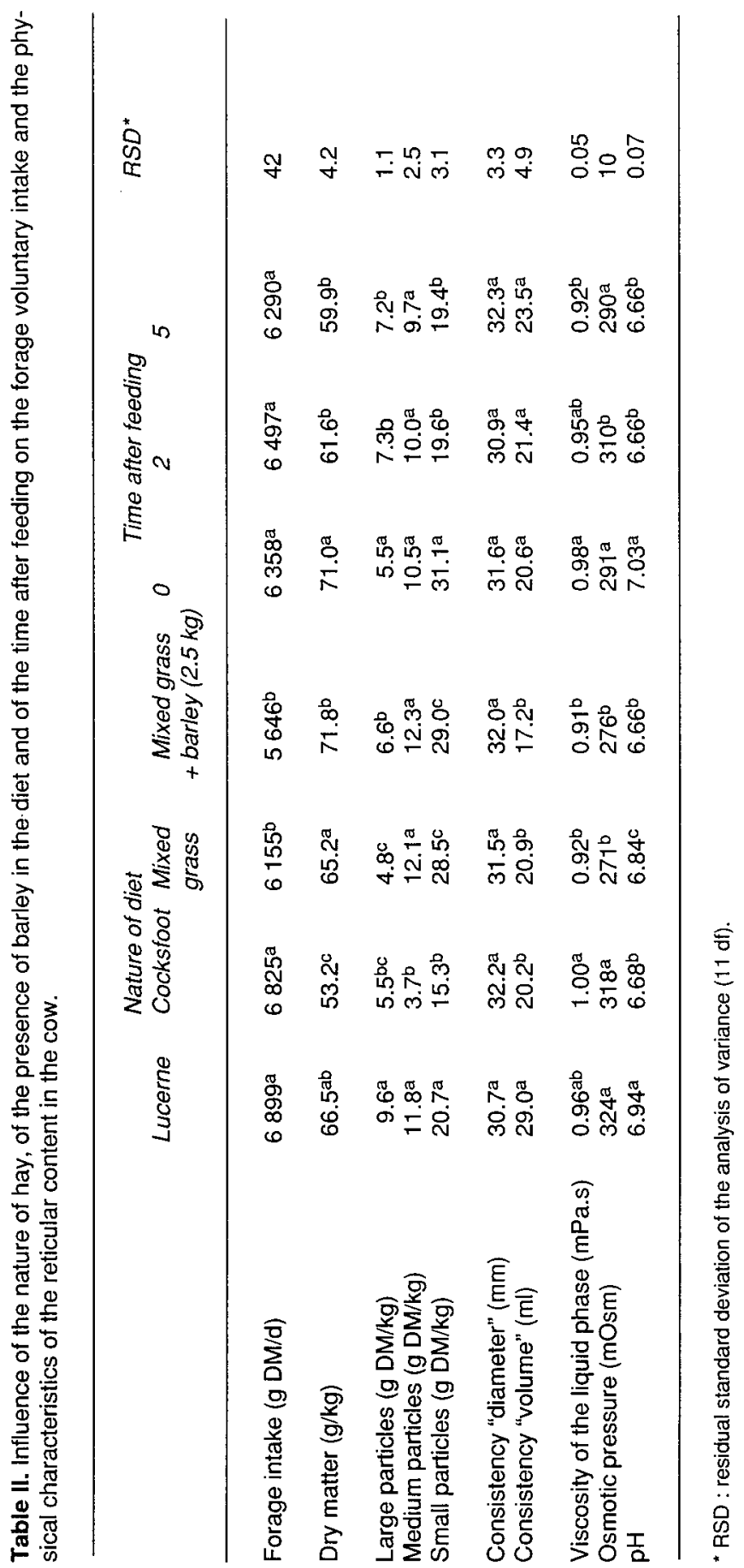


Dry matter values of reticular contents varied from under $50 \mathrm{~g} / \mathrm{kg}$ for fresh forages to over $100 \mathrm{~g} / \mathrm{kg}$ for lucerne pellets (tables II, IIi). Except for the pelleted diet, these values fell rapidly during feeding, but did not change between 2 and $5 \mathrm{~h}$ after feeding (table II). The DM content of final sieve effluent hardly varied; between 20 and 29 $\mathrm{g} / \mathrm{kg}$ for forages and 33 to $36 \mathrm{~g}$ for pellets. On the other hand, particulate DM varied much more widely; under $30 \mathrm{~g} / \mathrm{kg}$ with fresh forages, 25 to $45 \mathrm{~g} / \mathrm{kg}$ for hays and over $70 \mathrm{~g} / \mathrm{kg}$ with pellets. After feeding, the DM content of sieve effluent was barely or not at all lowered, while the particulate DM fell markedly. Hence it is this fall in particulate DM and not a dilution of soluble material that accounts for the fall in DM of the reticular content after feeding (tables II, III).

Large differences in particle size were observed among the different feeds: mixed grass hay with or without milled barley provided fewer large particles than other forages (tables II, III). Pellets provided practically no large particles because of the prior milling of the lucerne: accordingly, the amount of medium and small particles was 1.5 times higher than that observed with lucerne hay. For the other feeds, after intake the concentration of particles $>4 \mathrm{~mm}$ increased by $31 \%$ while that of particles $<1 \mathrm{~mm}$ decreased by $37 \%$ (table II). The results were identical 2 and 5 hours after feeding.

\section{Consistency of contents and viscosity of the liquid phase}

The minimum diameter of the orifice through which the reticular content will flow (consistency "diameter") is a direct function of the consistency, whereas the volume outflow through the $18-\mathrm{mm}$ orifice before plugging (consistency "volume") varies in- versely with the consistency. The coefficient of correlation between the values obtained by these 2 methods was highly significant overall ( $r=-0.693 ; n=68)$ and significant at least at $10 \%$ for each diet.

In the main study neither diet nor time of sampling had any effect on consistency "diameter" (table II), which was remarkably constant ( $31.6 \pm 1.5$ in the main study; $30.0 \pm 3.0$ for all the diets). Only the contents before feeding with fresh lucerne were markedly more fluid (table III).

Every time the hole in the basin was unstopped, 10 to $40 \mathrm{ml}$ of reticular content flowed out before formation of the plug. This consistency "volume" showed a greater residual standard deviation than the consistency "diameter". In the main study time of sampling had no significant effect on consistency "volume", but diet did; the outflow was 1.5 times greater with lucerne hay (table II). Fresh forages also provided more fluid content than hays. However, after the intake of lucerne pellets and to a lesser degree with milled barley, fluidity of the contents fell somewhat (table III).

The viscosity of the liquid phase maintained at $39^{\circ} \mathrm{C}$ was always low, and close to that of water at $20^{\circ} \mathrm{C}$. It varied little with the diet, but fell significantly with time after feeding, except for the fresh forages. No correlation with consistency was evident.

Overall, both the consistency "diameter" and the consistency "volume" were significantly correlated with DM content $(0.284, n$ $=68$ and $-0.464, n=68$, respectively), but though the consistency "diameter" was significantly correlated with the concentration of large particles $(0.369, n=68)$ of the total reticular content, the consistency "volume" was not. Multiple regression of the consistency "diameter" with DM and large particle concentration improved the correlation $(r=0.458)$, allowing consistency "diameter" to be predicted to within $5.74 \mathrm{~mm}$. 


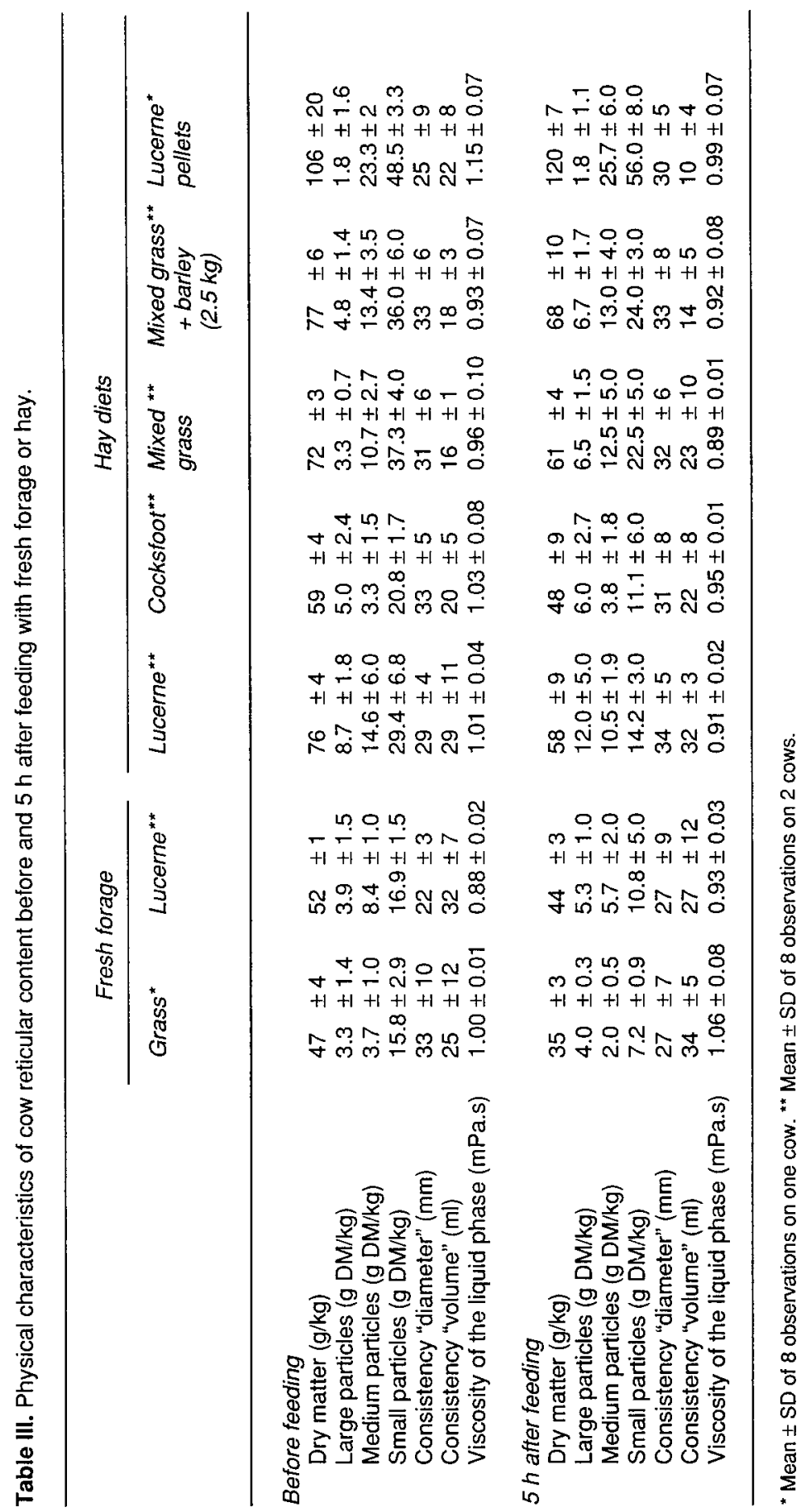




\section{pH and osmotic pressure}

$\mathrm{pH}$ fell in the usual manner after feeding (table II), most markedly with milled barley ( $0.7 \mathrm{pH}$ unit vs 0.3 overall).

Osmotic pressure rose during the first hours after feeding and reverted to prefeeding values by the 5 th $h$, except with added barley when it was lower 2 and $5 \mathrm{~h}$ after feeding than before. Osmotic pressure was significantly lower with mixed meadow grass hay than with the 2 other hays that contained more soluble material.

\section{Vertical distribution of particles under gravity and flow through an orifice}

After 10 minutes in the vertical distribution vessel, DM and particles accumulated significantly in the top and middle compartments; the particle content in the bottom compartment fell by 15 to $45 \%$ (fig 3 ). However, the DM values for the sieve effluents from the 3 compartments were similar. For all 4 diets in the main study, particle size distribution did not significantly differ in the 3 compartments, ie particles tended to rise to the top of the vessel regardless of size.

The fluid collected through the hole in the basin had 40 to $55 \%$ fewer particles than the total content (fig 3). However, the DM in the sieve effluent of this fluid was 5$20 \%$ higher. Overall, the DM value for the outflow was closely correlated with that of the reticular content $(0.912, n=68)$. Compared with the contents of the bottom compartment of the vertical distribution vessel, the outflow from the basin was even more depleted of particles, particularly large particles (fig 3). Thus under gravity, the bottom fraction was depleted of particles of all sizes whereas the filtration through an orifice favoured the removal of large particles.
The separation of particles under gravity and by flow through an orifice was more pronounced $2 \mathrm{~h}$ after feeding than before and was still evident $5 \mathrm{~h}$ after, by which time the bottom compartment was depleted of large particles by $50 \%$ and the outflow from the basin by $75 \%$ (fig 3 ).

As the analysis of variance did not reveal any interaction between effect of diet and time of sampling, we compared the effects of diet observed $5 \mathrm{~h}$ after feeding (fig 4). The particle depletion in the bottom compartment was much more marked with lucerne and cocksfoot hays than with mixed grass hay with or without milled barley. On the other hand, filtration through an orifice was more marked with mixed grass hay. With cocksfoot hay, almost all the small particles were let through, yet the large particles were retained to the same degree as with the other hays (fig 4). With lucerne pellets, there was practically no separating out under gravity; filtration through an orifice retained about half the large particles, which only actually accounted for $2.3 \%$ of total particulate matter. With fresh forages, separation under gravity was less marked than with the hays, essentially affecting the large particles. Particles were thus sorted as obtained by filtration through an orifice. This filtration was less efficient with fresh forages than with hays, but since the quantity of particulate matter in the total contents was smaller than with the hays (table III), it was correspondingly smaller in both the bottom compartment and in the outflow.

\section{DISCUSSION}

In this study we developed methods to study the consistency of the reticular content and the dynamics of the particles inside the reticulum as well as during the outflow through the ROO. The consistency of the reticular content was surprisingly constant 

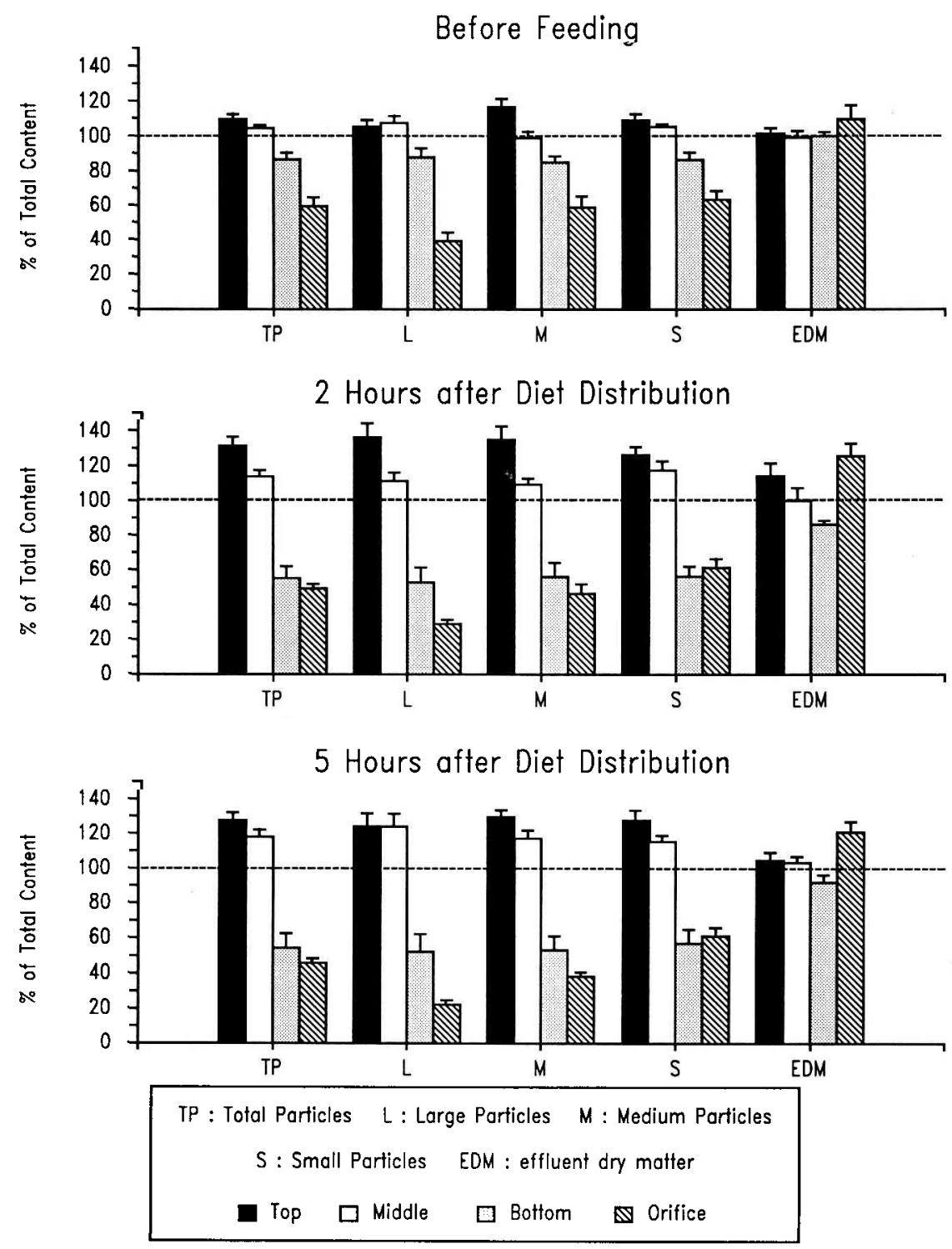

Fig 3. Influence of sampling time on content separation under gravity and by filtration through an $18-$ $\mathrm{mm}$ orifice. Each set of 4 columns represents, for a particular class of particles, the amount of dry matter per $\mathrm{kg}$ in the top, middle and bottom compartments and the fraction collected through an orjfice, as a percentage of the DM for that particle class per $\mathrm{kg}$ of total content (mean $\pm \mathrm{SEM}$ ). From left to right: total particle (TP), particles $>4 \mathrm{~mm}(\mathrm{~L})$, particles between $1-4 \mathrm{~mm}(\mathrm{M})$, particles between 0.05-1 $\mathrm{mm}(\mathrm{S})$ and final efflucent dry matter (EDM). 

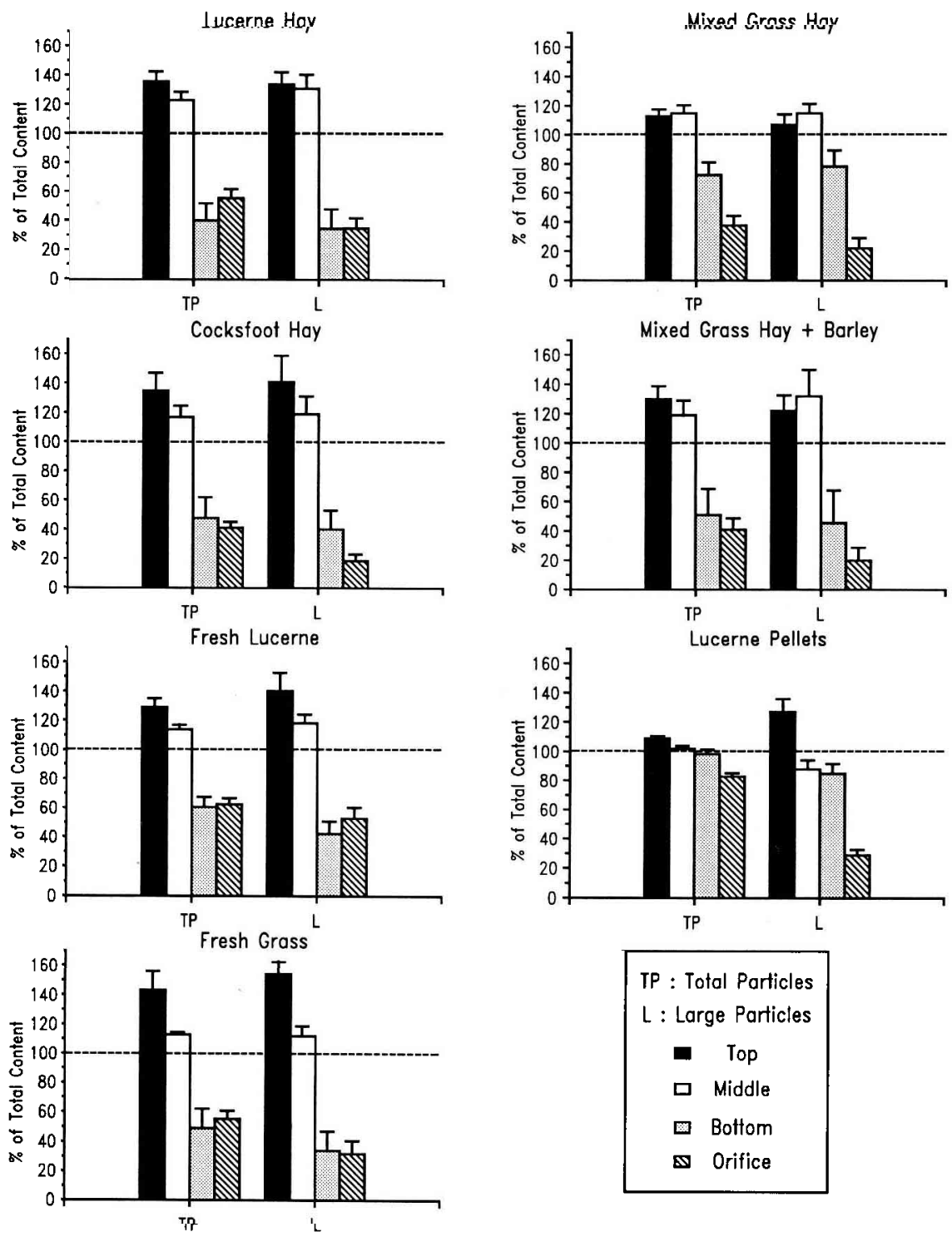

$$
\begin{aligned}
& \text { TP : Total Particles } \\
& L \text { : Large Particles } \\
& \text { - Top } \\
& \text { 口 Middle } \\
& \text { (⿴囗十) Bottom } \\
& \text { ه Orifice }
\end{aligned}
$$

Fig 4. Influence of diet on content separation under gravity and by filtration through an $18 \mathrm{~mm}$ orifice, $5 \mathrm{~h}$ after feeding. Mode of representation as in figure 3.

for different diets and sampling times. The dynamic behaviour of the particles in the reticular content was characterized by an ac- cumulation of all sizes of particles at the top of the contents resulting in a depletion of particles in the bottom of the contents. Dur- 
ing outflow, filtration of the contents at the ROO is added to the flotation of particles to allow only the passage of a low DM effluent and to retain in the reticulo-rumen the particles which need to be fermented.

\section{Particles and consistency of the reticular content}

During measurement of reticulo-omasal flow rate using an annular flow meter probe $33 \mathrm{~mm}$ in inside diameter (Dardillat, 1987), the occurrence of frequent occlusion indicated the importance of particle size and consistency in the emptying of the rumen.

The contents of the reticulum that originate from the bottom of the ventral sac are strongly depleted of particles compared with that from the dorsal sac of the rumen (Baumont and Deswysen, 1991). In this work, particle concentrations in the reticulum were 1.5 to 2 -fold lower than in the rumen, in agreement with Evans et al (1973). The decrease in reticular DM content and the increase in particle size after feeding are consistent with the results of Evans et al (1973) and Baumont et al (1992) in the reticulum and the bottom of the ventral sac that supplies it. The increase in the proportion of large particles is due to the high input of roughly masticated particles during ingestion. The fall in DM results from the high input of saliva (and drink) necessary to obviate an excessive rise in osmotic pressure due to the fermentation of soluble matter in the forage.

The wide range of diets studied resulted in correspondingly large differences in reticular content. The abundance of large particles in the reticulum with lucerne hay shows that these are less efficiently trapped in the rumen than those from other hays. Conversely, with cocksfoot hay, retention in the rumen of large- and particularly of medium-sized particles seems to be more efficient than with other hays, in agreement with the findings of Baumont et al (1992). The low dry and particulate matter encountered in the reticulum with fresh forages agrees with measurements made in the rumen (INRA, 1978). The very high DM content observed with lucerne pellets reflects a low degree of heterogeneity in the reticular content.

The parameter consistency was chosen since the physical concept of viscosity is applicable only to fluids that are heterogeneous only at the molecular level or which contain fine particles that do not interact with each other (Wolff, 1990). This is not the case for reticular content. There are few examples of measurements of consistency of fluids bearing large particles: for concrete mixes the method used is to measure the spreading diameter of the contents of a conical vessel emptied out onto a flat surface. This is not possible for gastric contents, which do not spread well and separate out into liquid and solid phases.

To measure consistency of rumen content, Welch's (1982) in vivo method based on the time a solid takes to rise when pulled by a constant force, though it cannot be applied to the reticulum, has the advantage of yielding results that can be interpreted unequivocally. For the reticulum, the measurement of the diameter of the orifice through which the contents can flow in their entirety is even simpler, and affords a concrete measure of the ability of a fluid to flow through an opening. This method is used to evaluate the consistency of powders (Flodex apparatus, Bioblock Scientific, Illkirch, France). The second method, where the volume let out through an orifice of a particular size is not general since it depends on the size of the orifice. This provides an additional evaluation of the ability of the contents to flow, and also enables the effects of filtration through an orifice to be appraised (Dardillat, 1990). 
The stability of the consistency "diameter" for different diets and sampling times suggests that content consistency is regulated. Salivation and rumination clearly favour the fluidification of the reticular content through lowering of dry matter concentration and particle size. The existence of tension-sensitive receptors in series with smooth muscle cells that are active during contraction of the wall (Leek, 1985) suggests that the consistency of the reticular content may be sensed. We know that the epithelial receptors which are sensitive to the fibrosity of the contents trigger rumination, but the effects of stimulation of the tension receptors on feeding behaviour and rumination are still little known (Reid, 1986). It may be that a momentary rise in consistency inhibits food intake and/or triggers rumination.

The consistency of the reticular content does not completely determine its ability to flow intermittently through an orifice; for similar consistency values, the contents flow much more readily with lucerne hay than with graminaceous hays, which may account for observed differences in duodenal flow (Malbert and Baumont, 1989).

The viscosity of the liquid phase was measured because of its importance in the filtration of the content through an orifice; a high viscosity binds the liquid phase to the particles, causing the 2 phases to move at the same rate, thereby curbing occlusion phenomena (Amidon, 1985). In the reticulum, the viscosity of the liquid phase is close to that of water, and its variations according to diet and sampling time are too slight to appreciably affect flow.

\section{Sorting of reticular content at the reticulo-omasal orifice}

The separation of the reticular content under gravity in the 3-compartment appara- tus results in an accumulation of all sizes of particles at the top. A similar distribution occurs in the rumen of the cow (Evans et al, 1973; Baumont et al, 1992) and the sheep (Sutherland, 1988). As the particles range in density from 1.03 to 1.18 in inverse proportion to their size, they might be expected to settle out rather than float up: however, these "functional" values were measured in density gradient columns (Evans et al, 1973) or using a pycnometer after slow spinning (Hooper and Welch, 1985), and though they take into account gas trapped within the particles they probably do not allow for gas bubbles attached to their surfaces. Hence these values do not fully predict the buoyancy of the particles in the rumen or reticulum. Sutherland (1988) using a method closer to ours, observed floating of particles over 1 $\mathrm{mm}$ in size and settling of smaller ones in samples from the ventral sac of the rumen of sheep fed lucerne hay. This sedimentation of small particles which we failed to observe may result from shaking during sampling, lengthy handling or dilution in artificial saliva, all of which are likely to cause release of attached gas bubbles.

Vertical movement of particles depends not only on gravity but also on their hydrodynamic resistance; this is proportional to their surface area and so is greater per unit mass for the smaller particles; thus large particles move faster than small ones. This may account for the preferential accumulation of large particles at the top of the apparatus $2 \mathrm{~h}$ after feeding with fresh forages. Also, particles may be buoyed up by gas bubbles formed within the liquid by fermentation. This effect is analogous to those exploited by the separation method known as flotation used in particular for waste water treatment, where the properties of different solid, liquid and gas interfaces enable separation (Barbery, 1989). Thus freshly ingested particles still coated with hydrophobic waxes will be borne up- 
wards by adherent gas bubbles more easily than digested particles that have become hydrophilic.

This flotation mechanism results in a depletion of particles in the bottom compartment, especially after feeding when many of the particles are still hydrophobic and production of gas abundant. In the reticulum, this separation can occur during the 1-min interval between 2 successive contractions. According to Reid (1984), the digesta that present themselves at the ROO when it opens come from the contents held between the ridges of the reticular honeycombs, ie a thickness of barely 1 $\mathrm{cm}$. This material may be depleted of particles to much the same extent as the content of the bottom compartment of the apparatus, which though some 10 times taller was left to separate for 10 times longer.

Filtration of the contents by passage through an 18-mm diameter hole is more efficient and above all more selective than flotation as regards retention of the large particles and recovery of the small ones. This selective retention of the large particles is consistent with the theory of Amidon (1985) according to which the time of transit of the particles is proportional to the square of their size, as confirmed for the pylorus in the dog. Unlike flotation, this filtration is still important in the animal before feeding. It naturally depends on the size of the orifice: according to McBride et al (1984), the open ROO measures 45 by $10 \mathrm{~mm}$, which justifies the choice of an 18$\mathrm{mm}$ diameter hole here, which gives the same perimeter. However, the volume collected through the $18-\mathrm{mm}$ orifice (20 to 30 $\mathrm{ml}$ ) is less than half that which flows through the ROO $(50-80 \mathrm{ml}$ in the cow according to Buéno (1975) and Dardillat (1987)). This may be because in the reticulum the contents that present themselves at the ROO are already depleted of particles and thereby more fluid, through prior flotation. In addition, filtration through a slit lined with papillae is certainly much more efficient than through a circular orifice: filtration at the ROO may well retain $70-80 \%$ of the large particles and $20 \%$ or so of the total DM, yielding a reticular effluent with $5 \%$ DM as recorded by Hauffe and von Engelhardt (1975) and Moir (1984).

\section{CONCLUSION}

Prolonged and continuous fermentation in the reticulo-rumen, which has evolved furthest in the bovine (Hofmann, 1988), is made possible by the homeostasis of the ruminal medium, and in particular by precise regulation of the evacuation of fermented digesta. This regulation is a combination of flotation, which carries large particles back to the rumen, and filtration, which stops them leaving it. These 2 passive processes determine the consistency of the content, which may be actively stabilized by adjustment of feeding patterns in response to signals from receptors on the reticulo-ruminal wall.

\section{ACKNOWLEDGMENTS}

The authors thank A Dardillat for skillful technical assistance.

\section{REFERENCES}

Amidon GL (1985) Fluid mechanics and intestinal transit. Gastroenterology 88,858

Barbery G (1989) Flottation, mécanismes et réactifs. In: Techniques de l'ingénieur. Séparation, Mélanges (Les Editions Techniques, Paris) A5 350, 1-16

Baumont R, Deswysen AG (1991) Mélange et propulsion du contenu du reticulo-rumen. $R e-$ prod Nutr Dev 31, 335-359 
Baumont R, Jamot J, Dardillat C, Grenet E (1992) Influence de la nature du foin et de r'état alimentaire sur la teneur en matière sèche et la granulométrie des digesta à différents niveaux du reticulo-rumen chez la vache. $6^{\theta}$ Journées Alimentation Nutr des Herbivores. Ann Zootech (in press)

Buéno $L$ (1975) Les fonctions motrices et digestives du feuillet. Thèse Doct Sci Nat Toulouse

Dardillat C (1987) Débit reticulo-omasal instantané chez la vache. Reprod Nutr Dév 27 IB, 231-232

Dardillat C (1990) Mesure d'écoulement du contenu réticulaire de vache. Reprod Nutr Dév suppl 2, 177s

Dardillat C, Baumont R (1988) Sur la rétention des particules de grande taille dans le réticulum chez la vache. Reprod Nutr Dév 28 (suppl 1), 137-138

Dardillat C, Baumont R (1992) Taille des particules alimentaires dans le canal et entre les lames omasales et dans les réservoirs amont et aval chez le bouvillon. Vle Journées Alimentation et Nutriton des Herbivores. Ann Zootech (in press)

Deswysen AG (1985) Forestomach control of digesta flow. In: The Ruminant Stomach (Ooms LA, Degryse AD, Marsboom R, eds) Proc Int Workshop, Antwerp, Belgium, 138-157

Ehrlein HJ (1980) Forestomach motility in ruminants. Publ Wiss Film Sekt Med N ${ }^{\circ}$ 9/C 1328, $29 \mathrm{pp}$

Evans EW, Pearce GR, Burnett J, Pillinger SL (1973) Changes in some physical characteristics of the digesta in the reticulo-rumen of cows fed once daily. Br J Nutr 29, 357-376

Grenet E (1970) Taille et structure des particules végétales au niveau du feuillet et des fèces chez les bovins. Ann Biol Anim Bioch Biophys 10, 643-657

Hauffe R, von Engelhardt W (1975) Funktionen des Blättermagens bei kleinen Hauswiederkaüern. 1. Zufluss und Verweildauer von festen Teilchen und von Flüssigkeit. $Z b /$ Vet Med A 22, 149-163

Hofmann (1988) Anatomy of the gastro-intestinal tract in the ruminant animal. In: Digestive Physiology and Nutrition (Church DC, ed) Prentice Hall, Englewood Cliffs, NJ, 14-44
Hooper AP, Welch JG (1985) Effects of particle size and forage composition on functional specific gravity. J Dairy Sci 68, 1181-1188

INRA (1978) Alimentation des Ruminants. INRA Publ, Versailles, France, $597 \mathrm{pp}$

Kennedy PM (1985) Effect of rumination on reduction of particle size of rumen digesta by cattle. Aust J Agric Res 36, 819-828

King KW, Moore WEC (1957) Density and size as factors affecting passage rate of ingesta in the bovine and human digestive tracts. J Dairy Sci 40, 528

Leek BF (1985) The control of the motility of the reticulo-rumen. In: The Ruminant Stomach (Ooms LAA, Degryse AD, Marsboom R, eds) Proc Int Workshop, Antwerp, Belgium, 1-17

Mackintosh JB (1984) Salivation, rumination and the passage of digesta through the forestomach of sheep. In: Ruminant Physiology, Concepts and Consequences (Baker SK, Grawthorne JM, Mackintosh JB, Purser DB, eds) Proc Symp Univ West Australia, 67-77

McBride BW, Milligan LP, Turner BV (1984) Endoscopic observations of digesta transfer from the reticulo-rumen to omasum of cattle. Can J Anim Sci 64 suppl 84-85

Malbert CH, Baumont R (1989) The effects of intake of lucerne (Medicago sativa $L$ ) and orchard grass (Dactylis glomerata) hay on the motility of the forestomach and digesta flow at the abomaso-duodenal junction of the sheep. Br J Nutr 61, 699-774

Moir RJ (1984) Why an omasum ? In: Ruminant Physiology, Concepts and Consequences (Baker SK, Gawthorne JM, Mackintosh JB, Purser DB, eds) Proc Symp Univ Western Australia, 85-93

Poppi DP, Norton BW, Minson DJ, Heindricksen RE (1980) The validity of the critical size theory for particles leaving the rumen. J Agric Sci (Camb) 94, 275-280

Reid CSW (1984) The progress of solid feed residues through the rumino-reticulum: the ins and outs of particles. In: Ruminant Physiology Concepts and Consequences (Baker SK, Gawthorne JM, Mackintosh JB, Purser DB, eds) Proc Symp Univ Western Australia, 79-84

Reid CSW (1986) Digestive physiology: the challenges today and tomorrow. In: Control of Digestion and Metabolism in Ruminants 
(Milligan LP, Grovum WL, Dobson A, eds) Prentice Hall, Englewood cliffs, NJ, 540-557

Statistical Analysis System Institute (1985) Statistical Guide for Personal Computers, Version 6. Statistical Analysis System Institute Inc, Cary, NC

Sutherland TM (1988) Particle separation in the forestomachs of sheep. In: Aspects of Digestive Physiology in Ruminants (Dobson A, Dobson MJ, eds) Cornell Univ Press, 43-73

Vaage AS, Shelford JA, Moseley G (1984) Theoretical basis for the measurement of particle length when sieving elongated particles. In: Techniques in Particle Size Analysis of Feed and Digesta in Ruminants (Kennedy PM, ed) Can Soc Anim Sci Occ Publ 1, 76-82
Waghorn GC, Reid CSW (1977) Rumen motility in sheep and cattle as affected by feeds and feeding. Proc NZ Soc Anim Prod 37, 176-181

Welch JG (1982) Rumination, particle size and passage from the rumen. $J$ Anim $S c i 54,885$ 894

Welch JG, Smith AM (1978) Particle sizes passed from rumen. J Anim Sci 46, 309

Wolff C (1990) Viscosité. In: Techniques de I'Ingénieur. Mesure et Contrôle. Les Éditions Techniques, Paris, R2350, 1-17

Wyburn RS (1980) The mixing and propulsion of the stomach contents of ruminants. In: Digestive Physiology and Metabolism in Ruminants (Ruckebusch Y, Thivend P, eds) MTP Press, Lancaster, 35-51 